\title{
An assessment of the tourist value of the Elblagg Canal
}

\author{
Tadeusz LIZIŃSKI I), Marcin BUKOWSKI ${ }^{2)}$
}

1) Żuławski Ośrodek Badawczy IMUZ, ul. Giermków 5, 82-300 Elbląg, Poland; tel. (55) 232-44-08, e-mail: imuz@pro.onet.pl

2) Katedra Ekonomiki Rolnictwa i Międzynarodowych Stosunków Gospodarczych, Szkoła Główna Gospodarstwa Wiejskiego, ul. Nowoursynowska 166, 02-787 Warszawa, Poland; tel. (22) 593-41-08, e-mail: marcin_bukowski@sggw.pl

\begin{abstract}
Canal connecting Elblag with Ostróda was built in the XIX century to transport corn to the port of Elblag. Due to economic and political changes it never played its economic function. Now it is a tourist attraction. The canal is thus of some tourist value which is difficult to assess. Tourist value of the Elblag Canal was assessed with the travel cost method (TCM) within the study carried out in 2003. The study allowed for estimating the object's value based on its usefulness expressed by inclination to payment. Three groups of users were distinguished when analysing the demand for recreational canal's services: tourists using ships of the Elbląg-Ostróda Navigation Company, individual sailors and anglers. Total tourist value of the canal calculated as NPV of the annual value of canal's services depends on adopted interest rate. At a rate of 3.2\% the value is 328 thous. PLN (73.9 thous. euro), at a rate of $4 \%-282$ thous. PLN (63.5 thous. euro), while at $8 \%$ interest rate it decreases to 160 thous. PLN (36.0 thous. euro).
\end{abstract}

Key words: environmental assessment, the Elblag Canal, travel cost method

\section{INTRODUCTION}

At present, the standard System of National Account (SNA) is commonly used in all OECD countries. Part of the SNA is the Gross National Product - commonly used and accepted measure of economic activity, development and wealth. It is underlined, however, that the system does not account for the value or changes in the total value of environmental resources. An illusion of prosperity might even be created when the increase of GNP is attained at the cost of environmental resources. To realize the concept of sustainable development through e.g. the use of economic-ecological accounting it will be necessary to evaluate environmental resources especially those of economic utility.

The Elblag Canal is an example of the natural and technical object (resource) used in economic activity which, however, has no fixed market value. The study 
was aimed at estimating the value of the Elblag Canal with the travel cost method. The assessment may enable further complete evaluation of associated areas and facilities.

There are many methods to estimate environmental value from both consumer's and producer's point of view. One of the methods most frequently used by environmental economists is the travel cost method (TCM) [SCHECHTER, 1996]. TCM is based on the assumption that the value people attribute to the environment is determined by the time needed to arrive to naturally attractive places and by travel costs. The method was developed and used mainly in the USA to measure the value of places used in mass recreation like national parks, nature reserves etc. Economic value of environmental resource estimated according to this method is a sum of values of:

- the time spent on recreation,

- travel costs,

- the difference between the costs of living at home and outdoor including tickets and other local charges.

There are two techniques of calculating demand curves in the TCM method:

- the technique of zonal travel costs,

- the technique of individual travel costs.

The second technique based on survey studies was used to estimate economic value of the canal. Single persons were asked in questionnaires about the number of visits per year, travel costs, lost earnings, costs of the time, accommodation costs, tickets and other local charges. Due to significant contribution of foreigners among respondents the questionnaire was prepared in Polish and English.

\section{STUDY OBJECT}

The Elblag Canal is situated in north-eastern Poland in warmińsko-mazurskie province (Fig. 1). In both technical and tourist respect it is one of most interesting water courses not only in Poland but also worldwide. Unique ramps and other objects constructed in the XIX century together with varied landscape along the course make the canal one of the type tourist attraction in Europe. The Elblag Canal is the longest navigable canal in Poland. Total length of its main sections is $129.8 \mathrm{~km}$. The length includes two lakes and three side branches of the canal. Main section Ostróda - Elbląg is $80.4 \mathrm{~km}$ long, Miłomłyn - Iława is $32.5 \mathrm{~km}$ long and Ostróda - Stare Jabłonki - Staszkowo - 16.9 km (Fig. 2).

Construction of the canal started in the beginning of the $19^{\text {th }}$ century. First assumption anticipated construction of a set of wooden chamber sluices (from 35 to 40 sluices each able to raise water level by $2.5-2.8 \mathrm{~m}$ ) to overcome the elevation difference of $99.5 \mathrm{~m}$ between Lake Druzno and lakes of Iława Lakeland. After con- 


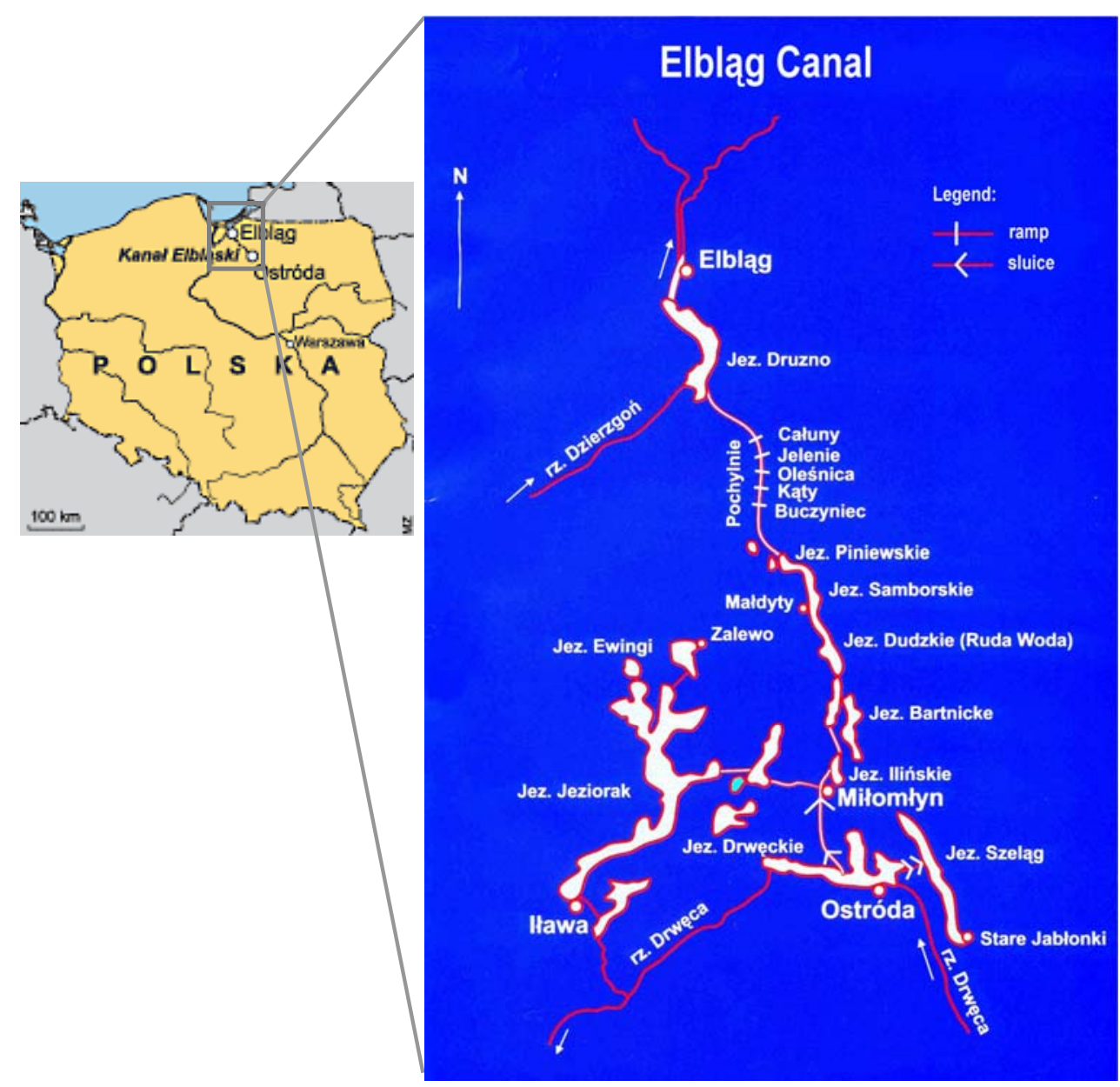

Fig. 1. Geographic position of the Elblagg Canal; source: JANUSZEWSKI [2001]

structing the first 5 sluices the concept was abandoned because of huge costs of exploitation of so many sluices.

In the years 1837-1844 Dutch engineer J. Steenke designed new project of the Elblag Canal and proposed to overcome the slope between lakes by using ship ramps unknown then in middle Europe (Fig. 2). Designed ramps allowed to move (on rails led on slopes 13-25 $\mathrm{m}$ high) ships of 50 DWT approaching from the upper and lower side. Total travel time through 5 ramps was 110 to $120 \mathrm{~min}$. Construction of the canal was resumed in 1852 .

Four ramps: Buczyniec (difference between levels $=20.6 \mathrm{~m})$, Katy $(18.9 \mathrm{~m})$, Oleśnica $(24.2 \mathrm{~m})$ and Jelenie $(22.0 \mathrm{~m})$ were built till the year 1860 . Between the years 1872 and 18764 sluices were constructed in Miłomłyn, Ostróda Zielona and Mała Ruś. The last ramp Całuny built in the years 1874-1881 replaced the already 


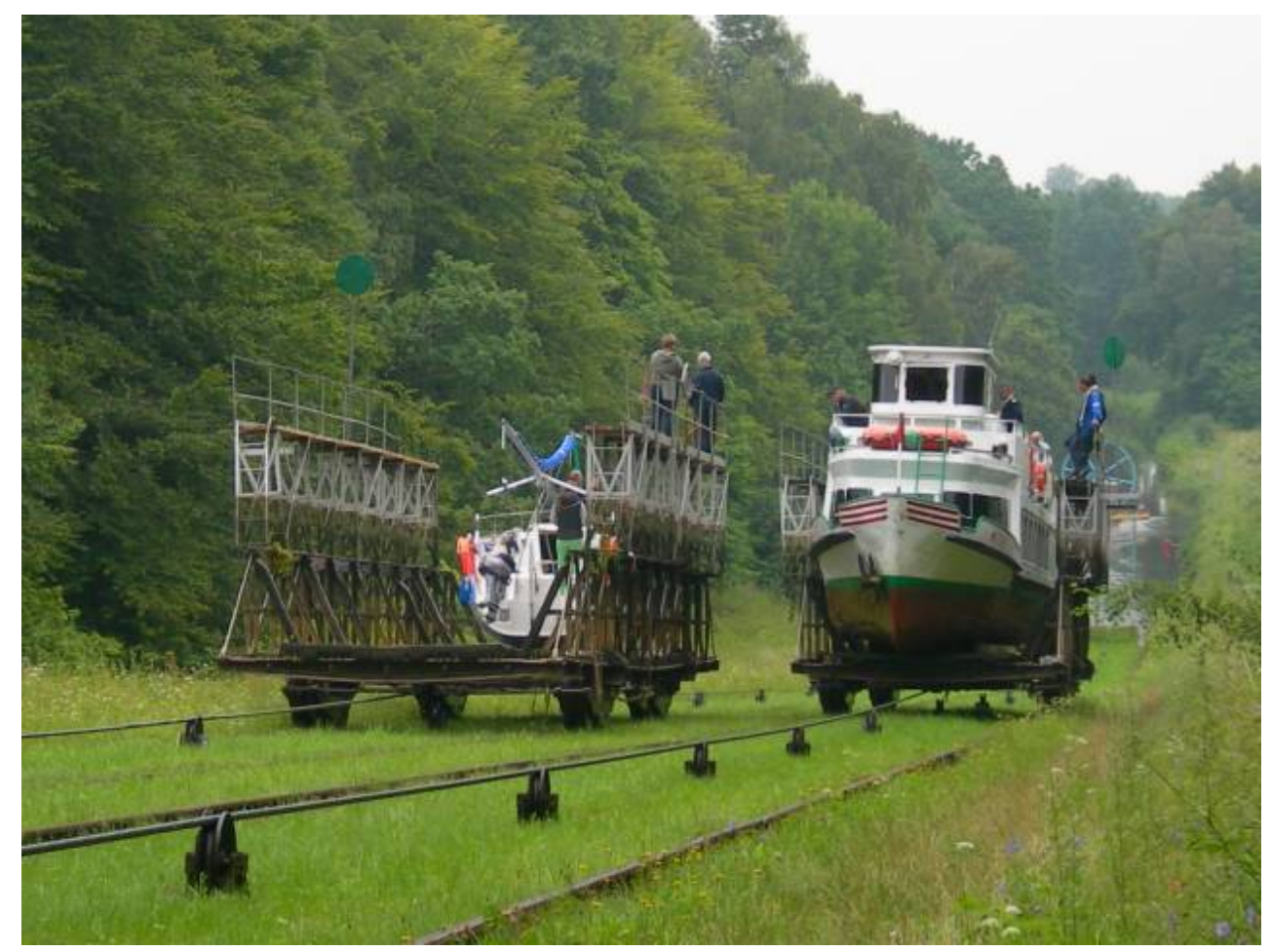

Fig. 2. Ramp in Buczyniec

(Source: http://www.gliwiczanie.pl/Reportaz/kanal_elblaski/buczyniec/buczyniec_02.htm)

existing wooden chamber sluices. Carts carrying ships up are powered by the energy of water flowing from upper to lower stands. Only the ramp in Całuny is equipped with electric Francis turbine [JANUSZEWSKI, 2001].

Construction of the canal was aimed at advancing economic development of that part of Olsztyn region where rich forest resources and abundant crop products called for the solution of transportation problems. Before building railroads and at missing roads these goods could not compete with products transported to Elblag and Gdańsk by water transport - much cheaper than road transport based in those days entirely on the horse power. The intention to stimulate economic activity in areas relatively close to the port of Elblag was not the only impulse to construct the canal. Other reason was the dynamic development of shipbuilding and boatbuilding in Elblag. This industry needed much high quality timber whose inexhaustible resources could be found in Iława Lakeland.

Economic importance of the canal decreased with the development of railroad and road transport and already in the $1930^{\text {th }}$ it was mainly seen as an attractive technical relic. It was formally confirmed in 1978 when its whole infrastructure was listed in a list of vintage buildings. Now, the canal is used exclusively for tour- 
ism. Basic fleet consists of five Diesel powered ships. Each may take 65 passengers on board and all are named after water birds: White-tailed eagle, Cormorant, Swan, Marabou and Penguin.

The importance of this object for Polish culture and heritage is evidenced by the fact that Elblag Canal was selected in the poll of the daily „Rzeczpospolita” among Seven Miracles of Poland. In this internet contest with over 82 thousand participants the canal was fifth on the list outstripping such known Polish monuments like Old Town in Gdańsk, Jasna Góra monastery or Łazienki Park in Warsaw [Oto..., 2007].

\section{METHODS}

The Elblagg Canal is the technical and natural object of recreation functions. It is impossible to distinguish associated polder facilities from the canal neither in technical, functional nor economic aspect. Polder facilities are integral parts of the canal being mainly the elements of flood control. They may be dealt with as the elements of technical infrastructure of multifunctional importance. Three main groups of users were distinguished when studying the demand for recreational services of the canal and associated polder facilities:

- tourists on board ships of the Elblag-Ostróda Navigation Company and of other carriers,

- sailors,

- anglers.

Annual value of the Elblag Canal was calculated from the equation estimating aggregated demand or its recreation services [LIZIŃSKI, 2007]

$$
W_{r}=L_{t \dot{z}}(P+Z+M)+L_{j p}\left(P_{z}+K_{c z}+M_{z}\right)+L_{w}\left(K_{w}+S_{w} \cdot W S\right)+O P
$$

where:

$W_{r}-$ annual value of the Elblag Canal,

$L_{t \dot{z}}$ - number of clients of the navigation company,

$P$ - per capita travel costs,

$Z$ - per capita lost earnings,

$M$ - local charges (accommodation, folders etc.),

$L_{j p}$ - number of recreational boats - private or chartered,

$P_{z}$ - travel costs of the crew members,

$K_{c z}$ - cost of the charter (per day),

$M_{z}$ - local costs of the crew members

$L_{w}$ - number of anglers,

$K_{w}-$ travel costs of an angler, 
$S_{w}-$ fee for annual license to fish in waters belonging to a given Angler's Association,

$W S$ - the ratio of the canal waters to the total area of fishing grounds,

$O P$ - charges for the Regional Board of water Management.

Travel costs of tourists using ships of the Elblagg-Ostróda Navigation Company were estimated with the survey method (questionnaires). Obtained results and information from the Elblagg-Ostróda Navigation Company allowed for estimating travel costs of these tourists.

Travel costs of individual sailors were estimated based on official information from the Regional Board of Water Management (RBWM), own observations and opinions collected from the employees of the RBWM. Travel costs of anglers were estimated from data gathered in the Regional Board of Polish Anglers Association (PAA) in Elblag. For both groups the method of approach zones was applied. Results of calculations are given in PLN and euro acc. to the exchange rate from the middle of 2003 (100 euro $=444.29$ PLN) [Roczne..., 2007].

\section{RESULTS}

a) Individual tourists

Survey was made in July-August 2003 and covered 118 persons during 6 passages up and down the ramp in Buczyniec. Characteristic of the studied group is presented in Table 1. In the carrier's opinion the group can be considered representative in view of both age and national structure.

Most tourists, both country and foreign, combine the travel by ship in the canal with visits to other places. Only 12 persons in the studied groups $(11.2 \%)$ said the only reason of their travel was sightseeing the canal. For other polled people one day travel on the canal was part of the longer stay in that part of Poland and most often was combined with travels to Malbork, Gdańsk, Olsztyn or to the seashore. Similarly touring character was typical for foreign trips whether organised or individual. Therefore, it was important to estimate the share of costs associated with travel to the canal in total costs of the travel from home to holiday place. This share was estimated as follows:

- according to the time of stay at the canal to the total holiday period,

- according to the share of costs of approaching the canal to the total travel costs,

- according to the importance of desire to see the canal in making the decision to travel.

Different travel costs were obtained depending on the way of calculation. The first two methods produced similar results. According to the first variant (prices of 2003) travel cost for Polish tourist was 38.02 PLN (8.56 euro) and for foreign tourist - 154.67 PLN (34.84 euro). Respective costs for the second variant were: 33.30 
Table 1. Characteristic of surveyed group

\begin{tabular}{|c|c|c|c|}
\hline Criterion & Category & Number & Share in $\%$ \\
\hline \multirow[t]{5}{*}{ Nationality } & Poles & 23 & 19.5 \\
\hline & Germans & 89 & 75.4 \\
\hline & Britishers & 3 & 2.5 \\
\hline & Frenchmen & 2 & 1.7 \\
\hline & Italians & 1 & 0.9 \\
\hline \multirow[t]{6}{*}{ Age } & $<20$ & 5 & 4.5 \\
\hline & $21-30$ & 3 & 2.7 \\
\hline & $31-40$ & 11 & 10.0 \\
\hline & $41-50$ & 14 & 12.7 \\
\hline & $51-70$ & 63 & 57.3 \\
\hline & $>71$ & 14 & 12.8 \\
\hline \multirow[t]{7}{*}{ Distance, $\mathrm{km}$} & $<200$ & 9 & 7.6 \\
\hline & $201-500$ & 7 & 5.9 \\
\hline & $501-750$ & 25 & 21.2 \\
\hline & $751-1000$ & 22 & 18.6 \\
\hline & $1000-1500$ & 35 & 29.7 \\
\hline & $1501-2000$ & 19 & 16.1 \\
\hline & $>2000$ & 1 & 0.9 \\
\hline \multirow[t]{7}{*}{ Means of transportation ${ }^{1)}$} & on foot/bike & 14 & 11.9 \\
\hline & car & 34 & 28.8 \\
\hline & van & 8 & 6.8 \\
\hline & bus & 7 & 5.9 \\
\hline & aircraft & 11 & 9.3 \\
\hline & train & 20 & 16.9 \\
\hline & vehicle & 48 & 40.7 \\
\hline
\end{tabular}

${ }^{1)}$ Multiple answers possible.

PLN (7.5 euro) and 146.52 PLN (33.0 euro). So high similarity might result from the fact that polled persons estimated travel costs based on the time they spent on the canal to the total time of holiday. Results obtained with the third method were over two times (Poles) and four times (foreign tourists) higher than those obtained acc. to the first two methods. The discrepancy stemmed from the fact that part of polled people gave the desire to see the canal as the main reason of their trip to this region of Poland. In that case a large part of total travel costs (sometimes up to 75$-90 \%$ ) should be calculated as the cost of approaching the canal. In further calculations travel costs were estimated based on the time of stay.

In part of polled tourists it was impossible to divide travel costs into transport costs and local charges since in organised trips (particularly for foreign tourists) 
participants paid all travel and accommodation costs together. For this group the cost of stay was calculated as a mean prise of a day in two-star hotel in Elblag enlarged by the cost of tickets and other expenses declared by polled persons. Mean costs of stay (ticket for the cruise, folders, maps, accommodation and full board) calculated for Polish tourists were 131.31 PLN (29.57 euro) and 164.77 PLN (37.11 euro) for foreign tourists.

Only three polled persons gave the values of lost salaries. Large part of visitors spent their holiday that way, so they did not lost their salaries. Pensioners who do not have a possibility of alternative earning dominated among foreign tourists. Therefore, this element of calculation was omitted. By analogy, this element was also omitted in the group of individual sailors and anglers.

The Elblag-Ostróda Navigation Company reported they had 35707 clients. Based on performed survey it was assumed that 28923 persons in that group were foreigners and 6784 were Polish tourists. Annual value of the Elbląg Canal acc. to the travel costs of tourists sailing the ships of the Elblag-Ostróda Navigation Company was thus 10400869 PLN (2 342538 euro).

\section{b) Sailors}

The next studied group consisted of individual sailors including members of the crews of sailing yachts, motorboats and kayaks passing sluices and ramps. The canal due to its location is the main waterway connecting the Vistula and Nogat with Iława Lakeland and the Great Masurian Lake District. For this reason the highest density of sailing boats could be observed in May-June when boats are bound for Masuria and in September when the boats return to their home ports. In summer time water facilities of the canal are used mainly by tourists sailing on kayaks, motorboats and smaller boats rented in the port of Elblag.

Data on this group of users came from the reports of the Regional Board of Water Management in Gdańsk and from interviews with workers employed at ramps. Based on these sources it was found that:

- in the year 2002 the canal served 940 boats including 820 sailing yachts which at an average crew of 3.5 persons makes 2870 persons in total,

- mean time of their stay in the canal is 1 day,

- mean charter cost is c. $100 \mathrm{PLN} \cdot \mathrm{day}^{-1}\left(22.52\right.$ euro $^{-}$day $\left.^{-1}\right)$,

- 85\% sailors are not from Elblag - most of them are from Torun, Bydgoszcz, Gdańsk, Gdynia, Łódź, Olsztyn, Warsaw, Katowice and Kędzierzyn-Koźle. Based on yacht markings recorded in books at ramps the adopted distribution of approaching distance is as that presented in Fig. 3.

It was adopted that mean cost of approaching the canal for a yacht's crew was 61.60 PLN, local costs (food, fuel) equaled 26.60 PLN. Annual value of the Elblag Canal acc. to the costs borne by individual sailors (including costs of chartering yachts) was 154324 PLN (3 458 euro). 


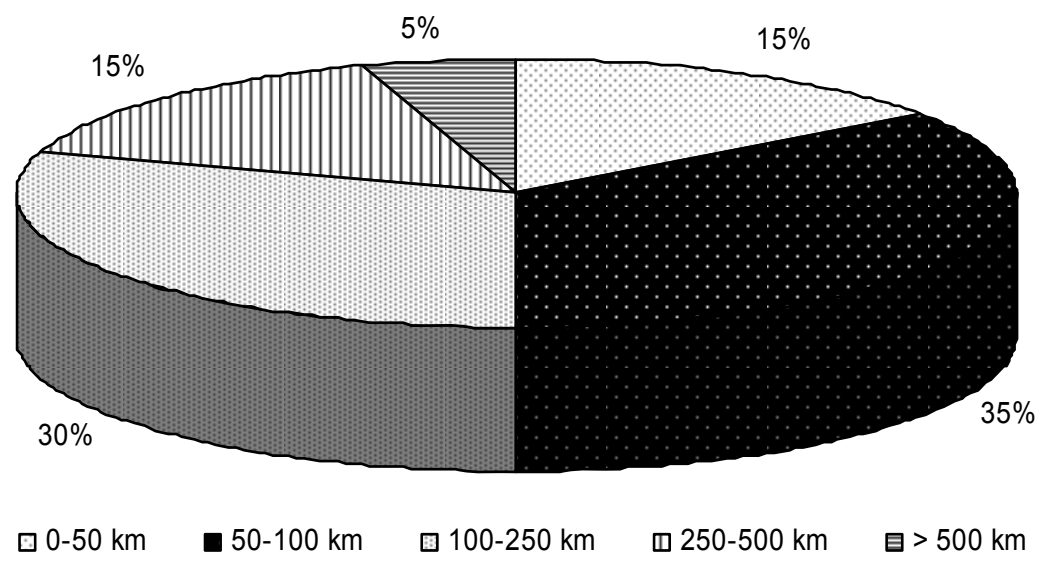

Fig. 3. Distribution of yachtsmen numbers according to their distance of travel

\section{c) Anglers}

The last group of users of the Elblag Canal waters are anglers. Value of the object acc. to the costs of that group was estimated from information of the Regional Board of the Polish Anglers Association in Elblag. The data include the number of anglers using depression and near-depression part of the canal, number of fishing days and fishing charges (Tab. 2). The following assumptions were adopted when calculating travel costs of anglers group:

- frequency of fishing in the canal waters for members of angling circle in Gdańsk - twice a month during the whole season (April to October) and four times a month for members of other circles,

- travel cost per $1 \mathrm{~km}$ is equal to the rate used in 2003 to reimburse the use of private car in business trips $\left(0.4798 \mathrm{PLN} \cdot \mathrm{km}^{-1}\right)$.

Table 2. Characteristic of studied group of anglers

\begin{tabular}{l|c|c|c|c}
\hline $\begin{array}{c}\text { Anglers } \\
\text { circle in }\end{array}$ & $\begin{array}{c}\text { Number } \\
\text { of members }\end{array}$ & Distance & $\begin{array}{c}\text { Travel cost } \\
\text { PLN per year }\end{array}$ & $\begin{array}{c}\text { Members' fee } \\
\text { PLN per year }\end{array}$ \\
\hline Gdańsk & 400 & 130 & 349294.40 & 24000 \\
Elblag & 1800 & 5 & 120909.60 & 108000 \\
Pasłęk & 360 & 20 & 96727.68 & 21600 \\
Młynary & 360 & 35 & 169273.44 & 21600 \\
Rychliki & 360 & 15 & 72545.76 & 21600 \\
Markusy & 360 & 20 & 96727.68 & 21600 \\
Gronowo Elbląskie & 360 & 25 & 120909.60 & 21600 \\
Total annual costs & & & 1266388 PLN (231 169 euro) \\
Per 1 angler & & & 316.6 PLN (57.8 euro) \\
\hline
\end{tabular}


According to the Water Act [Ustawa, 2001] the use of waterways and water facilities is charged. The level of these charges is established by directives of the Minister of Environment.

During the study period the charge for passing the sluice or ramp was, according to the Directive of 29. March 2002 [Rozporządzenie, 2002]:

- for ship - 11.30 PLN,

- for yacht or other ships of deadweight less than $15 \mathrm{t}-5.30$ PLN,

- for kayak and motorboat - 3.00 PLN.

Based on binding rates and the number of vessels sailing through sluices and ramps it was calculated that the sum of charges paid for RBWM in 2003 for using water facilities was 103912 PLN (23 404 euro).

Substituting calculated values to eq. (2) annual value of the Elblag Canal services was estimated at 11925493 PLN (2 685922 euro).

Because the canal is a natural and technical object of limited durability, present value of annual services was then calculated for predicted period of further exploitation. History of the object shows that the time span between subsequent larger reconstructions is c. 100 years. The last reconstruction took place in 1965 so estimated lifetime of the canal in its present form is 60 years. Assuming unchanged popularity of the canal the Net Present Value (NPV) of the stream of annual services was calculated for this period. The size of macroeconomic interest rate is needed to calculate this value. For the purpose of this study an interest rate of long term bank deposits was adopted here. For the study period the rate was $3.2 \%$ [Roczne..., 2007; Podstawowe..., 2007]. To analyse the susceptibility to this basic parameter the rate of $8 \%$ was applied according to the branch instruction [Metodyka..., 1976]. Moreover, the rate of $4 \%$ was used proposed by Weitzman [after MANTEUFFEL and KUBICKA, 2007] as a mean rate appropriate to discount environmental goods in the opinion of a worldwide representation of environmental economists. The value of the canal in relation to adopted discount rate is presented in Table 3.

Table 3. Value of the Elblag Canal in relation to the discount rate

\begin{tabular}{l|c|c|c}
\hline \multirow{2}{*}{ Value of the Canal } & \multicolumn{3}{|c}{ Discount rate, \% } \\
\cline { 2 - 4 } & 3.2 & 4 & \multicolumn{1}{c}{8} \\
\hline In PLN & 328292488 & 281721782 & 159521982 \\
In euro & 73939750 & 63450852 & 35928374 \\
\hline
\end{tabular}

\section{CONCLUSIONS}

The study shows that a natural and technical object like the Elblag Canal has large economic value. Depending on adopted interest rate this value ranges from 
150 million do 370 million PLN (from 36 to 74 million euro). Part of this value should be attributed to embankments that determine existence of the canal in its present form. The study proves also the usefulness of the TCM method in evaluating resources of no market value. The method could be used to assess various strategies of flood control differing in environmental effects.

\section{REFERENCES}

1. BARTCZAK A., 1997. Wycena wartości czystej wody metodą kosztów podróży. Pr. magist. (An assessment of the value of clean water with the method of travel costs. MSc. thesis). Warszawa, Uniwersytet Warszawski, Katedra Mikroekonomii.

2. DubGAARD A., 2004. Cost-benefit analysis of wetland restoration. J. Water Land Dev. 8: 87-102.

3. JANUSZEWSKI S., 2001. Kanał Elbląsko-Ostródzki. (The Elbląg-Ostróda Channel). Wrocław, Studio Artystyczno-Reklamowe „TAK”.

4. LIZIŃSKI T., 2007. Problemy zarządzania ryzykiem w kształtowaniu i ocenie przestrzeni polderowej na przykładzie Delty Wisły. (Risk management problems in the formation of polder area based on the Vistula Delta example). Woda Środ. Obsz. Wiej. Rozpr. nauk. monogr. nr 21: 171.

5. MANTEuffel H., KuBicka E., 2007. Makroekonomiczna efektywność rekultywacji jeziora. W: Uwarunkowania i mechanizmy zrównoważonego rozwoju. (Macroeconomic effectiveness of lake restoration. In: Determinants and mechanisms of sustainable development). Mater. 6 Międzyn. Konf. Nauk. Białystok, Tallin, 2-5 lipca 2007. Białystok, Wydaw. WSE: 265-276.

6. Metodyka określania ekonomicznej efektywności inwestycji wodnych, melioracyjnych i zaopatrzenia wsi w wodę. (Methods of estimating economic effectiveness of water and land reclamation investments and water supply in rural areas). Instrukcja branżowa, 1976. Warszawa, IMUZ, MR.

7. Oto siedem cudów Polski, 2007. (Here are seven miracles of Poland). Rzeczpospolita, 221, 21.09.2007: 1 .

8. PANASIUK D., 2001. Wycena środowiska metodą kosztów podróży w praktyce. Wartość turystyczna Pienińskiego Parku Narodowego. W: Ekonomia a rozwój zrównoważony. T. 2. Wdrażanie. (Environmental assessment with the method of travel costs in practice. Tourist value of the Pieniny National Park. In: Economy and sustainable development. Vol. 2. Implementation). Białystok, Wydaw. Ekon. Środ.: 264-277.

9. Podstawowe stopy procentowe NBP w latach 1989-2007, (Basic interest rates of the National Bank of Poland in the years 1989-2007), 2007. NBP. www.nbp.pl/dzienne/

10. Rozporządzenie Ministra Środowiska z dnia 29 marca z 2002 r. w sprawie należności za korzystanie ze śródlądowych dróg wodnych oraz urządzeń wodnych. (Directive of the Minister of Environment of 29 March 2002 on payments for using inland waterways and water facilities). Dz. U. $2002 \mathrm{nr} 55$ poz. 494.

11. Roczne wskaźniki cen towarów i usług konsumpcyjnych w latach 1950-2006, (Annual indices of prices of goods and services in the years 1950-2006) 2007. Warszawa, GUS. www.stat.gov.pl/gus/

12. Rocznik statystyczny RP, (Statistical yearbook), 2004. Warszawa, GUS.

13. SHeCHTER M., 1996. Wycena środowiska W: Ekonomia środowiska i zasobów naturalnych. (Environmental assessment. In: Economy of the environment and natural resources). Red. H. Folmer, L. Gabel, H. Opschoor. Warszawa, Wydaw. Krupski i s-ka: 193-213.

14. Ustawa z dnia 18 lipca 2001 r. Prawo wodne. (Water Act of 18 July 2001). Dz.U. 2001 nr 115 poz. 1229 . 


\section{STRESZCZENIE}

\section{Wycena wartości turystycznej Kanału Elbląskiego}

Słowa kluczowe: Kanał Elblaski, metoda kosztów podróży, wycena środowiska

Oryginalny kanał łączący Elbląg z Ostródą, zbudowany w XIX wieku, miał za zadanie transport zboża do portu w Elblągu. Ze względu na zmiany gospodarcze i polityczne nigdy nie pełnił zakładanej funkcji gospodarczej. Obecnie stanowi atrakcję turystyczną. Kanał stanowi więc pewną wartość turystyczną, ale trudną do oszacowania. W ramach przeprowadzonych w 2003 r. badań dokonano wyceny wartości turystycznej Kanału Elbląskiego metodą kosztów podróży (TCM). Umożliwiło to określenie wartości tego obiektu na podstawie jego użyteczności, wyrażonej przez skłonność do zapłaty. Badając popyt na usługi rekreacyjne Kanału, wyróżniono trzy grupy użytkowników: turystów korzystających ze statków Żeglugi Ostródzkiej, indywidualnych żeglarzy oraz wędkarzy. Całkowita wartość turystyczna Kanału, obliczona jako NPV wartości rocznej usług Kanału, zależna jest od przyjętej stopy procentowej. W przypadku stopy procentowej 3,2\% wartość ta równa się 328 tys. zł (73,9 tys. euro), dla stopy procentowej 4\% - 282 tys. zł $(63,5$ tys. euro), zaś gdy stopa procentowa równa jest $8 \%$ wynosi ona 160 tys. zł (36,0 tys. euro).

Reviewers:

Prof. Stanistaw Lojewski

Prof. Waldemar Mioduszewski 